\title{
Ossification of anterior sacroiliac ligament and its clinical significance
}

\author{
SINGH, R.* \\ Department of Anatomy, AIIMS Rishikesh, 249201, UK, India \\ *E-mail: nani_sahayal@rediffmail.com
}

\begin{abstract}
Introduction: Sacrum articulates on either side of the innominate bones forming sacroiliac joints. The joint is strengthened by anterior sacroiliac ligament anteriorly and dorsal sacroiliac ligament posteriorly. Weight of the body is transmitted from sacrum to iliac bone mainly through sacroiliac ligaments. Sacroiliac joint becomes important while treating ankylosis and degenerative diseases in pelvis. It exhibits number of variations with age. Materials and Methods: During osteology demonstration classes of first year MBBS students of KG Medical University Lucknow, UP, India, author came across a dry male pelvis having partial ossification of anterior sacroiliac ligament connecting the sacrum and ilium in left side. Results: The right SI Joint was not ossified. Only left antero-superior part of the anterior sacroiliac ligament was ossified and rest was not ossified. The length of ossified part of ligament was $4.5 \mathrm{~cm}$ and remaining part of the same was $6.5 \mathrm{~cm}$. On the dorsal surface, posterior sacroiliac and interosseous ligaments were not ossified. There was no ankylosis of sacroiliac joint but the coccyx was fused with tip of sacrum. The probable cause of ossification may be genetic or more weight transmission through this ligament due to shifting of centre of gravity as a result of leaning of the body in left side on account of disease, trauma or pathological conditions. Conclusion: This Case report brings out an unreported anatomical variant of partial ossification of anterior sacroiliac ligaments. The knowledge will be of paramount importance to clinicians for pain, to radiologists for misinterpretation of radiographs and to anatomists for new variant.
\end{abstract}

Keywords: sacrum, iliac bone, ankylosis, sacroiliac joint, coccyx.

\section{Introduction}

Sacroiliac (SI) joint is largest axial joint. It is diathroidial joint consisting of two types of articulating surfaces:

1.Antero-inferior synovial joint between the auricular surface of sacrum and ilium.

2. Postero-superior syndesmosis between interosseous surfaces of ilium and sacrum.

SI Joint surfaces are irregular with ridges and depressions that are reciprocal and better developed in males. These irregular surfaces restrict the movements and contribute to the strength of the joint and thus enhancing the stability during weight transmission from vertebral column to lower limbs. Though irregular surfaces of the joint help in maintaining the stability but slight antero-posterior rotation occurs around the transverse axis of the joint. These movements occur more in pregnant women than in normal men and women (STANDRING, 2005). Several muscles such as gluteus maximus, piriformis and ligaments like anterior and posterior sacroiliac ligaments surrounding the joint influence the movement and stability of this joint (COHEN, 2005). Ankylosis or fusion and ossification of adjacent ligaments may constrain the movement of the joint. Muscles and ligaments acting on SI Joint traverse the joint both in front and behind can be causes of pain and inflammation if these joints are in dysfunction (ROSATELLI, AGUR and CHHAYA, 2006).

In the present case author observed partial ossification of anterior sacroiliac ligament of dry left male pelvis. This is a unique variant of partial ossification of anterior sacroiliac ligament therefore, it is worth presenting as a case report.

\section{Case Report}

During osteology demonstration classes of first year MBBS students of KG Medical University Lucknow, UP, India, author came across a dry male pelvis having partial ossification of anterior sacroiliac ligament connecting the sacrum and ilium in left side (Figure 1).

The right SI Joint was not ossified. Only left antero-superior part of the anterior sacroiliac ligament was ossified and rest was not ossified. The length of ossified part of ligament was $4.5 \mathrm{~cm}$ and remaining part of the same was $6.5 \mathrm{~cm}$. On the dorsal surface, posterior sacroiliac and interosseous ligaments were not ossified.

There was no ankylosis of sacroiliac joint but the coccyx was fused with tip of sacrum. There was no other abnormality in this sacrum and innominate bone.

\section{Discussion}

SI Joint is true diarthoidial joint with large surface area with an average of $17.5 \mathrm{~cm}^{2}$ (BERNARD and CASSIDY, 1991). This joint is mainly designed for stability and its main function is to transmit weight of the trunk to lower limbs. Stability of joint is provided by intrinsic ligaments i.e. anterior sacroiliac ligament in ventral region, posterior and interosseous ligaments in dorsal region and extrinsic ligaments- sacrotuberous and 


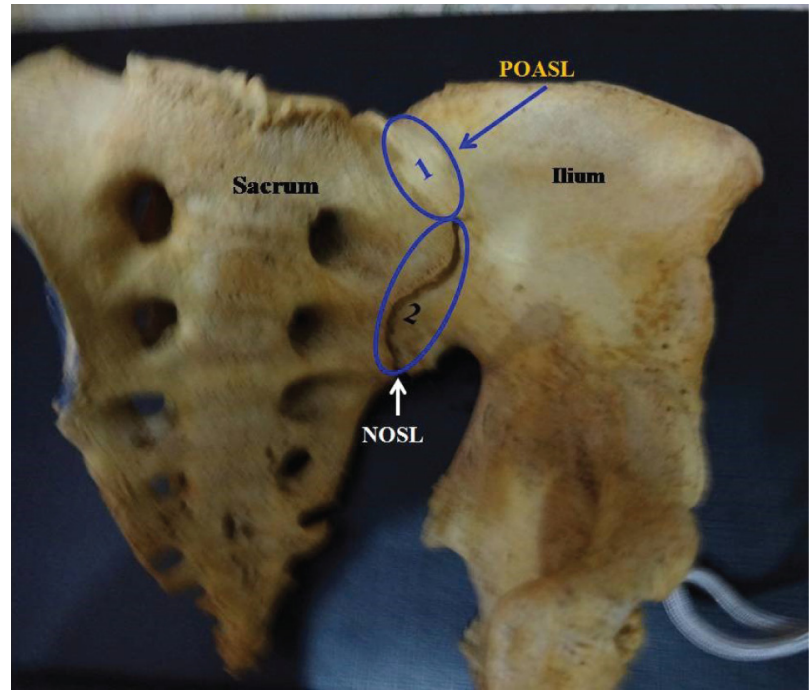

Figure 1. Shows ventral aspect of left side of male pelvis with ossification of anterior sacraoilliac ligament. POASL - partial ossification of anterior sacroiliac ligament, NOSL - non ossified part of sacroiliac ligament.

sacrospinous ligaments (PUHAKKA, MELSEN, JURIK et al., 2004). In the erect position of the body, body weight is transmitted on to sacrum may cause anterior tilt of sacrum. This is prevented by posterior sacroiliac and sacrutuberous ligaments which act as automatic locking device or screw home mechanism (DONTIGNY, 1985). Bilateral ankylosis of SI Joint, ossification of sacrotuberous, sacrospinous and transverse ligaments were observed (SHARMILA and SANKAR, 2011) according to which sacroiliac ankylosis is strictly confined to males. During child birth SI Joint become lax and hence less prone to ankylosis of this joint in females. Strength and stability are sacrificed for more mobility in females after puberty and in pregnancy (BROOKE, 1924).

In the present case author observed partial ossification of anterior sacroiliac ligament of male pelvis on left side. It may be due to shifting of centre of gravity laterally from tip of coccyx which on the other hand might have been caused by any disease or pathological reasons like scoliosis, polio, shortening of leg, paralysis of gluteus medius and minimus, dislocation of hip joint etc. In such conditions more weight of the body is born by anterior sacroiliac ligament which may lead to its ossification.

In this case, besides partial ossification of the anterior sacroiliac ligament, coccygeal sacralisation has also been observed which might have been caused by modulated effect of Hoxllgroup of gene (BURKE, NELSON, MORGAN et al., 1995) and Paxl/Pax9 paralogous genes (WALLIN, WILTING, KOSEKI et al., 1994).

In radiographs, these ossified ligaments between sacrum and illium appear as ribs or digits (MCGLONE, HAMILTON and FITZ GERALD, 2000). Within abdomen and pelvis these anomalies are known as sacral or pelvic ribs or digits (GOYEN, BARKHAUSEN, MARKSCHIES et al., 2000). Proper knowledge of this variant is essential for interpretation of radiographs, accurate diagonosis and treatment of dysfunction of SI Joint. The extra material deposited due to ossification of anterior sacroiliac ligament on the joint may compress the vessels and structure passing in the vicinity of ossified region creating complications to the patients. The sacralisation and the ossification appear to be associated anomalies to be confirmed by clinicians.

Acknowledgements: Author is thankful to the head of department for providing the material for the study. No grant has been received from any institution or company. There is no conflict of interest.

\section{References}

BERNARD, TN. and CASSIDY, JD. The sacroiliac syndrome: pathophysiology, diagnosis and management. In: FRYMOYER, JH. (Ed.). The adult spine: principles and practice. New York: Raven, 1991. p. 2107-2130.

BROOKE, R. The sacroiliac joint. Journal of Anatomy, 1924, vol. 58, n. Pt 4, p. 299-305. PMid:17104023.

BURKE, AC., NELSON, CE., MORGAN, BA. and TABIN, C. Hox genes and the evolution of vertebrate axial morphology. Development, 1995, vol. 121, n. 2, p. 333-346. PMid:7768176.

COHEN, SP. Sacroiliac joint pain: a comprehensive review of anatomy, diagnosis and treatment. Anesthesia and Analgesia, 2005, vol. 101, n. 5, p. 1440-1453. http://dx.doi.org/10.1213/01. ANE.0000180831.60169.EA. PMid:16244008.

DONTIGNY, RL. Function and pathomechanics of the sacroiliac joint: a review. Physical Therapy, 1985, vol. 65, n. 1, p. 35-44. PMid:3155567.

GOYEN, M., BARKHAUSEN, J., MARKSCHIES, NA. and DEBATIN, JF. The pelvic digit: a rare development anomaly, a care report with CT correlation and review of the literature. Acta Radiologica (Stockholm, Sweden), 2000, vol. 41, n. 4, p. 317-319. http://dx.doi. org/10.1080/028418500127345569. PMid:10937749.

MCGLONE, BS., HAMILTON, S. and FITZ GERALD, MJ. Pelvic digit: an uncommon developmental anomaly. European Radiology, 2000, vol. 10, n. 1, p. 89-91. http://dx.doi.org/10.1007/s003300050010. PMid:10663721.

PUHAKKA, KB., MELSEN, F., JURIK, AG., BOEL, LW., VESTERBY, A. and EGUND, N. MR imaging of the normal sacroiliac joint with correlation to histology. Skeletal Radiology, 2004, vol. 33, n. 1, p. 15-28. http://dx.doi.org/10.1007/s00256-003-0691-4. PMid:14614576.

ROSATELLI, AL., AGUR, AM. and CHHAYA, S. Anatomy of the interosseous region og the sacroiliac joint. The Journal of Orthopaedic and Sports Physical Therapy, 2006, vol. 36, n. 4, p. 200-208. http:// dx.doi.org/10.2519/jospt.2006.36.4.200. PMid:16676869.

SHARMILA, B. and SANKAR, KD. Bilateral ankylosis of sacroiliac joint with ossified sacrospinous, sacrotuberous and transverse acetabular ligaments. Int J of Anat Variations, 2011, vol. 4, p. 123-127.

STANDRING, S. Gray's Anatomy: anatomical basis of clinical practice. 39th ed. London: Elsevier Churchill Livingstone, 2005. p. 1428-1442.

WALLIN, J., WILTING, J., KOSEKI, H., FRITSCH, R., CHRIST, B. and BALLING, R. The role of paxl in axial skeleton development. Development, 1994, vol. 120, n. 5, p. 1109-1121. PMid:8026324.

Received December 27, 2013

Accepted October 23, 2015 